\title{
Psychosocial impact of COVID-19-related quarantine: reflections after the first case of suicide in Colombia
}

\author{
Impacto psicosocial de la cuarentena debido \\ a la COVID-19: reflexiones tras el primer \\ caso de suicidio en Colombia
}

\author{
Impacto psicossocial da quarentena pela \\ COVID-19: reflexões sobre o primeiro \\ caso de suicídio na Colômbia
}

\author{
Jairo M. Gonzalez-Diaz 1,2 \\ Juan Fernando Cano 1,3 \\ Victor Pereira-Sanchez 4
}

doi: 10.1590/0102-311X00117420

Two months after the World Health Organization (WHO) declared COVID-19 a pandemic, Colombia has reported over 10,000 confirmed cases of the disease and 400 deaths. On March 25, 2020, a stayat-home (SAH) order was issued country-wide to prevent the spread of the virus. After that, media channels reported the suicide of a middle-aged man in Santa Marta, a city located on the Caribbean coast. At least three times, authorities had scold him for violating the SAH order, and he claimed at court that, for working as a street vendor, he would not be able to feed his family if forced to stay at home. According to the media, his arrest might play a role in his suicide ${ }^{1}$.

However, this is not an isolated case. Similar events have been reported worldwide: Bangladesh 2 and India ${ }^{3}$ have likewise reported cases of suicide related to COVID-19 in which xenophobia, stigma, and fear of contagion may have contributed.

Nunes recently stated that individuals' vulnerabilities imposed by their social context determine how they experience this global pandemic 4. This is particularly important considering that socioeconomic determinants pose risk factors for suicide, reaching beyond person-centered preventive efforts. In fact, economic difficulties and unemployment are major "suicidal drivers" among the Colombian population 5,6, and economic inequality is intrinsically associated with the country's suicide rates 7 . Considering the impact of this pandemic in the global economy and that economic downturns and infectious outbreaks seem to increase suicide rates 8,9 , we could be facing a potential "perfect storm" 10.

Crisis situations, as COVID-19 outbreak, highlight the longstanding social inequalities in our continent. Thus, when implementing strategies to minimize SAH adverse effects, governments should consider self-isolation impact on populations' mental health 11. Yet more concerning is the fact that 79\% of Colombian households depending on informal jobs are considered ineligible for the wage subsidies provided by the government's relief measures during the current COVID-19 lockdown 12.

Government's priority during the current pandemic must be to implement an integrative approach for mitigating adverse mental health outcomes and providing accessible mental health services. Suicide prevention should be at the forefront of these preventive efforts. In this regard, we suggest strengthening public health surveillance for mental health focusing on vulnerable groups, educating our communities in psychological first aid, limiting mental health professionals redeployment, creating and maintaining hotlines for suicidal crisis, and resorting the roles that primary healthcare and social lead-
1 Escuela de Medicina y Ciencias de la Salud, Universidad del Rosario, Bogotá, Colombia. 2 Clinica Nuestra Señora de la Paz, Bogotá, Colombia. 3 Centro de Investigaciones del Sistema Nervioso, Bogotá, Colombia.

4 Department of Child and Adolescent Psychiatry, NYU Grossman School of Medicine, New York, U.S.A.

Correspondence J. M. Gonzalez-Diaz Centro Rosarista de Salud Mental, Escuela de Medicina $y$ Ciencias de la Salud, Universidad del Rosario. Calle 12C, n. 6-25, Bogotá DC / 111711, Colombia. jairom.gonzalez@urosario.edu.co 
ers play in our communities 13,14. Besides, media-outlets must keep combating fake news and misinformation, following good practice in suicide reporting, and providing information on mental health, well-being and suicide prevention 15. Finally, during and after COVID-19 pandemic, mental health professionals should look for and apply evidence-based and culturally-adapted interventions to assist their patients and communities, providing a real-time response using the available digital means 16,17 .

\section{Contributors}

J. M. Gonzalez-Diaz conceived the main idea. All authors contributed to the writing consecutive drafts and final manuscript.

\section{Additional informations}

ORCID: Jairo M. Gonzalez-Diaz (0000-0003-12388447); Juan Fernando Cano (0000-0003-40879534); Victor Pereira-Sanchez (0000-0002-25761549).

\section{References}

1. Urieles R. Hallan cuerpo sin vida de vendedor tras sanción por violar cuarentena. El Tiempo 2020; 17 apr. https://www.eltiempo.com/ colombia/otras-ciudades/vendedor-en-santamarta-sancionado-por-violar-cuarentena-fuehallado-muerto-485896.

2. Mamun MA, Griffiths MD. First COVID-19 suicide case in Bangladesh due to fear of COVID-19 and xenophobia: possible suicide prevention strategies. Asian J Psychiatr 2020; 51:102073.

3. Goyal K, Chauhan P, Chhikara K, Gupta P, Singh MP. Fear of COVID 2019: first suicidal case in India! Asian J Psychiatr 2020; 49:101989.

4. Nunes J. The COVID-19 pandemic: securitization, neoliberal crisis, and global vulnerabilization. Cad Saúde Pública 2020; 36:e00063120.

5. Arenas A, Gómez-Restrepo C, Rondón M. Factores asociados a la conducta suicida en Colombia. Resultados de la Encuesta Nacional de Salud Mental 2015. Rev Colomb Psiquiatr 2016; 45 Suppl 1:68-75.

6. García-Valencia J, Palacio-Acosta C, Diago J, Zapata C, López G, Ortiz J, et al. Eventos vitales adversos y suicidio: un estudio de autopsia psicológica en Medellín, Colombia. Rev Colomb Psiquiatr 2008; 37:11-28.

7. Campo-Arias A, Herazo E. Asociación entre desigualdad y tasa de suicidio en Colombia (1994-2013). Rev Colomb Psiquiatr 2015; 44:28-32.

8. Oyesanya M, Lopez-Morinigo J, Dutta R. Systematic review of suicide in economic recession. World J Psychiatry 2015; 5:243.

9. Cheung YT, Chau PH, Yip PSF. A revisit on older adults suicides and severe acute respiratory syndrome (SARS) epidemic in Hong Kong. Int J Geriatr Psychiatry 2008; 23:1231-8.

10. Reger MA, Stanley IH, Joiner TE. Suicide mortality and coronavirus disease 2019: a perfect storm? JAMA Psychiatry 2020; [Online ahead of print].

11. Gonzalez Diaz J, Lozano-Lesmes L, CampoArias A. Comment on "Mental health: why it still matters in the midst of a pandemic". Braz J Psychiatry 2020; [Online ahead of print].

12. Jaramillo ID, Londoño D, Rodríguez P, GarzíaSuaza A. La vulnerabilidad del mercado laboral colombiano al COVID-19. https://www. labourosario.com/post/la-vulnerabilidad-delmercado-laboral-colombiano-al-covid19 (accessed on 22/Apr/2020).

13. Ransing R, Adiukwu F, Pereira-Sanchez V, Ramalho R, Orsolini L, Schuh Teixeira AL, et al. Early career psychiatrists' perspectives on the mental health impact and care of the COVID-19 pandemic across the world. Asian J Psychiatr 2020; 51:102085.

14. Gunnell D, Appleby L, Arensman E, Hawton K, John A, Kapur N, et al. Suicide risk and prevention during the COVID-19 pandemic. Lancet Psychiatry 2020; 7:468-71.

15. Reidenberg DJ, Niederkrotenthaler T. Reporting on suicide during the COVID-19 pandemic. https://save.org/wp-content/up loads/2020/04/Reporting-on-Suicide-Dur ing-COVID19-Pandemic-Apr20.pdf (accessed on 22/Apr/2020).

16. Smith K, Ostinelli E, Cipriani A. Covid-19 and mental health: a transformational opportunity to apply an evidence-based approach to clinical practice and research. Evid Based Ment Health 2020; 23:45-6.

17. Chevance A, Gourion D, Hourtel N, Llorca PM, Thomas P, Bocher R, et al. Ensuring mental health care during the SARS-CoV-2 epidemic in France: a narrative review. Encephale 2020; [Online ahead of print].

Submitted on 08/May/2020

Approved on 12/May/2020 